\title{
CHANGES IN DECISION MAKING SKILL AND SKILL EXECUTION IN SOCCER PERFORMANCE: THE INTERVENTION STUDY
}

\author{
Rudolf Psotta, Andrew Martin*
}

\author{
Faculty of Physical Culture, Palacký University, Olomouc, Czech Republic \\ * School of Management, Massey University, Palmerston North, New Zealand
}

Submitted in June, 2011

BACKGROUND: Previous studies have provided controversal results on the development of the skills of decision making skill and skill execution when tactical models of the teaching of a game were used.

OBJECTIVE: The purpose of the study was to examine the effects of two different combined technical-tactical instructional models on the development of decision making skill and ball skill execution during a soccer match in female students.

METHODS: Two groups of female students aged $20.9 \pm 0.7$ years underwent the 5 week soccer training intervention, consisting of two $90 \mathrm{~min}$. training units a week, based on the technical-tactical model with an emphasis on orientation to tactical and technical skills, respectively (CTA and CTE students, respectively). Before and after the intervention, students' decision making skill and ball skill execution in a match were assessed from videorecords of matches using the Soccer Performance Observation System (SPOS). In addition, the Soccer skill test battery (Mor \& Christian, 1979) was used to assess the ball skills under control environment.

RESULTS: The Skill Execution Index (SEI) after intervention in both CTA and CTE students $(0.58 \pm 0.15$ and $0.65 \pm 0.11)$ found using SPOS were significantly higher in comparison to SEI before the intervention $(0.46 \pm 0.13$ and $0.50 \pm 0.09 ; p<0.05$ and $p<0.01$ ). Similarly, the Decision Making Index (DMI) was significantly enhanced after intervention in the cases of both CTA students (from $0.70 \pm 0.14$ to $0.81 \pm 0.12, p<0.05$ ) and CTE students (from $0.65 \pm 0.11$ to $0.75 \pm 0.12$, $\mathrm{p}<0.05$ ).

CONCLUSIONS: This study showed that instructional models with both dominant tactical tasks and dominant technical tasks can result in the significant improvement of both decision making and skill execution performance in young adult subjects. The study suggested that both decision making in game situations and ball skill execution can be developed through implicit learning.

Keywords: Motor learning, teaching of games, tactical skill, implicit learning, technical skill, soccer.

\section{INTRODUCTION}

Game performance in sport games is underlied by the perceptual-cognitive processes leading to decision making about movement response and senso-motor processes responsible for skill execution. Thus, development of game performance is generally seen in learning tactical and technical skills, and their integration into the game context (Mitchell, Oslin, \& Griffin, 2006; Gréhaigne, Richard, \& Griffin, 2005).

There has been considerable debate about how much emphasis should be placed on technical skills, and how much on players' awareness of game tactics and their decision making skills to improve game performance (Starkes, Ericsson, \& Anders, 2003; Williams \& Hodges, 2004). The tactical model of teaching was derived from ideas of the teaching games for understanding (TgfU) model (Mitchell, Oslin, \& Griffin, 2006; Butler \& Cahan, 2005) and presented a shift from an instructional approach emphasising learning technical skills called the traditional or technical model (Rink, French, \& Tjeerdsma, 1996), for the dominant style of teaching of decision making skills. In the tactical model, teaching technical skills is reduced and follows after the understanding and practice of particular tactical principles, so that movement execution skills are learned in closer connection with the particular tactical problem (Mitchell, Oslin, \& Griffin, 2006; Rink, French, \& Tjeerdsma, 1996). However, previous studies on the effects of the tactical model in some sport games provided mixed or controversal results when this model did not demonstrate significant benefits in the development of both the cognitive and motor components of game performance in comparison to the technical based instructional models (Harrison, Blakemore, Richards, Oliver, Wilkinson, \& Fellingham, 2004; French, Werner, Taylor, Hussey, \& Jones, 1996; Turner \& Martinek, 1995).

The skill oriented instructional models as models based on content development (Rink, 1998) or mastery learning (Bloom, 1976) showed similar effects on the im- 
provement of decision making skills and skill execition in a match as a tactical model (Harrison, Blakemore, Richards, Oliver, Wilkinson, \& Fellingham, 2004; Harrison, Preece, Blakemore, Richards, Wilkinson, \& Fellingham, 1999). Even, the instructional blocks focused on skill execution, applied in sufficient frequency and time volume, could seem to provide an important condition for the effective development of game performance, when decision making skills can be developed more easily than movement execution skills (McPherson, \& French, 1991).

The evidence mentioned above suggests that integrated teaching tactics and techniques could be beneficial for the improvement of the game performance of players. However, there are almost no studies on the effects of the combined technical and tactical models of teaching. Only three intervention studies which investigated the effects of the tactical model involving also blocks of teaching skill execution have been published (Harrison, Blakemore, Richards, Oliver, Wilkinson, \& Fellingham, 2004; Turner \& Martinek, 1992, 1995). However, in these studies, no information about the frequency and/or time volume of instruction devoted to skill execution and decision making skills is available. Therefore, the purpose of the study was to examine the effects of two differently combined instructional models on the development of a player's decision making skill and skill execution during a match in female students - soccer beginners.

\section{METHODS}

\section{Participants}

Two groups of female students of physical education $(n=2 \times 12)$ aged $20.7 \pm 0.8$ years and $21.0 \pm 0.7$ years participated in this study. Students with experience in the systematic training of any team sport were not included into these groups. One university teacher of sport pedagogy with a specialisation in sport games instruction/training and experienced in soccer coaching served as a teacher for the intervention study after his systematic preparation for the study.

\section{Training intervention}

Two 5 week training programs based on differently combined technical-tactical models were applied simultaneously during the basic course of soccer in the two groups of students mentioned above. The content of the both programs was structured into five two-lesson cycles, i.e. one cycle a week, with a $90 \mathrm{~min}$. duration of each lesson.

In both training programs, teaching technical skills concerned offensive skills - basic manipulative skills, various techniques of dribbling, passing, receiving a ball under control, overcoming an opponent in situation 1 on/vs. 1 and shooting, further linking these skills into chains as the serial skills and their application of various situations. Teaching offensive tactical skills included principles for running without a ball (supporting a teammate, calling for a ball, timing runs to a goal), principles for acting after winning a ball in a defensive zone, after being in possession during the building up of the attack phase (through the middle zone) and after being in possession in an offensive zone and close to the goal of the opponent team. As a supplement, defensive tactics were taught - principles for acting after losing a ball, building up the defence, covering space, marking an opponent in possession, covering space behind a teammate's marking, pressing and shifting the block of players to the ball. Also, basic information related to both offensive and defensive tactics for standard situations such as the throw in, cornering and the free kick were provided to the students.

The difference between both models consisted in:

a) The different time needed for teaching tactical and technical skills - in the CTA model $85 \mathrm{~min}$. and 25 min. a week, respectively; in the CTE model $25 \mathrm{~min}$. and $85 \mathrm{~min}$. a week, respectively (TABLE 1 ).

b) The different time of students' practice in a controlled predictable learning environment and an open unpredictable environment (TABLE 1). In the CTA model technical skills were taught under controlled conditions in a predictable learning environment, i.e. using skill drills and type 1 game exercises (the classification of instructional forms according to Dobrý, 1988; for definitions see TABLE 1) for $25 \mathrm{~min}$. a week while in the CTE model in a controlled environment for $65 \mathrm{~min}$. plus $20 \mathrm{~min}$. per week using a variable, unpredictable environment, i.e. game exercises of type 2 and training games (Dobrý, 1988; see the definitions in TABLE 1). In the CTA model, tactical skills were taught for $85 \mathrm{~min}$. in an open, unpredictable environment, while, in the CTE model, 25 min. of a match were used, with a teacher's verbal instructions related to tactics. In addition, both models involved a 40 min. match without any teacher's verbal instructions, each week (TABLE 1). For lessons, one half of a grass field with diameters in accordance with the official soccer laws was available.

\section{Treatment validation}

To check the type of instructions, all lessons were videorecorded by the two videorecorders, and audiotaped with the teacher's verbal intervention. From the video and audiorecords of each lesson, a description of each task was done to indicate: a) the focus in terms of the technical or tactical task; b) specific tactical or technical skills taught; c) the instructional form, i.e. type of learning environment; d) time spent on each task.

After each lesson, a researcher and a teacher who taught in both treatment programs, evaluated the tech- 


\section{TABLE 1}

The CTA and CTE instructional models of soccer training intervention

\begin{tabular}{|c|c|}
\hline The CTA model & The CTE mo \\
\hline $\begin{array}{l}\text { 1. Each 1st lesson of a given two-lesson (weekly) cycle included the f } \\
\text { - } 10 \text { min. warm up - skill drills (no teacher's verbal intervention), } \\
\text { static and dynamic stretching. } \\
\text { - } 25 \text { 's-min. teaching on the ball skills using two forms of controlled } \\
\text { predictable learning environment: } \\
\circ \text { skill drills (without an opponent), } \\
\text { type I game exercises (with an opponent) repeated reproduc- } \\
\text { tive execution of patterns of actions. } \\
\text { In these two instructional forms, teacher's verbal interventions } \\
\text { (instructions, demonstrations, feedbacks, corrections and explana- } \\
\text { tions) solely related to technique. } \\
\text { - } 50 \text { min. teaching tactical skills using two forms of learning envi- } \\
\text { ronment with less controlled, variable, unpredictable conditions } \\
\text { to stimulate appropriate decision making: } \\
\circ \text { type II game exercises, i.e. repeated game actions with defined } \\
\text { ending - one or more player executes offensive/defensive } \\
\text { tasks against opposition players - patterns of actions are not } \\
\text { prescribed, } \\
\text { modified games, i.e. size and/or shape of a field, no. of play- } \\
\text { ers, rules, number/placement of goals and number of balls, } \\
\text { according to a tactical focus, } \\
\text { in these two instructional forms, teacher's verbal interven- } \\
\text { tions mentioned above solely related to tactics. }\end{array}$ & $\begin{array}{l}\text { llowing blocks } \\
\text { - } 10 \text { min. warm up as in the CTA model. } \\
50 \text { min. teaching on the ball skills divided into two: } \\
\quad 1^{\text {st }} \text { phase } 30 \text { min. - using two types of controlled, predictable } \\
\text { learning environments - skill drills and type I game exercises, } \\
\quad 2^{\text {nd }} \text { phase } 20 \text { min. - using less controlled, unpredictable, vari- } \\
\text { able learning environments with type II exercises and modi- } \\
\text { fied games. } \\
\text { In both phases, teacher's verbal interventions were solely related } \\
\text { to technique. } \\
\text { - } 25 \text { min. teaching tactical skills using a } 5 \text { on five match with tea- } \\
\text { cher's verbal interventions. } \\
\text { Type I game exercise: } \\
\text { controlled predictable learning environment a game with one player } \\
\text { or group of players under the presence of opponent (one or more) } \\
\text { players execute one discrete model of action. } \\
\text { Type II game exercise: } \\
\text { - open unpredictable learning environment, } \\
\text { - teacher does not provide way of solving game situations, for } \\
\text { example the offensive action of four players against three players } \\
\text { with one goal, some rules can be added, for example, two touches } \\
\text { and so on. }\end{array}$ \\
\hline $\begin{array}{l}\text { 2. Each } 2 \text { nd lesson of a given two lesson (weekly) cycle included the } \\
\text { - } 10 \text { min. warm up as in the first lesson (see above). } \\
\text { - } 35 \text { min. refining/reinforcement of tactical skills taught in first les- } \\
\text { son, using the type II game exercises/modified games, teacher's } \\
\text { verbal interventions solely related to tactics. } \\
\text { - } 40 \text { min. } 5 \text { on } 5 \text { match (including } 4 \text { min. half time for recovery) } \\
\text { with no teacher's verbal intervention, i.e. no explicit instruction. }\end{array}$ & $\begin{array}{l}\text { following blocks: } \\
\text { - } 10 \text { min. warm up as in the CTA model (see above), } \\
\text { - } 35 \text { min. refining/reinforcement of technical skills taught first } \\
\text { lesson - skill drills/type I game exercises, teacher's verbal inter- } \\
\text { ventions related to technique, } \\
\text { - } 40 \text { min. } 5 \text { on } 5 \text { match (including } 4 \text { min. half time for recovery) } \\
\text { with no teacher's verbal intervention (no explicit instruction). }\end{array}$ \\
\hline
\end{tabular}

nical and tactical performance of students in particular tasks based on the observation of videorecords to modify appropriately the tasks planned for the next lesson.

The video and audio-analysis of tasks confirmed a different total instructional time devoted to technical and tactical skills in the CTA and CTE model: the total instructional time for technical tasks $95 \mathrm{~min}$. vs. 309 min., i.e. for the CTA students $30.7 \%$ of time of the CTE students; for tactical tasks $330 \mathrm{~min}$. vs. $125 \mathrm{~min}$., i.e. for the CTA students $264 \%$ of time of the CTE students, and a match without the teacher's verbal instruction 169 min. vs. 176 min., i.e. for the CTA students 96\% of time of CTE students.

In the case of the CTA students, the total instructional time devoted to technical tasks involved $84 \%$ of the total practice time and $16 \%$ of the total teacher's verbal intervention time; the total instructional time of tactical tasks involved $82 \%$ of the total practice time and $18 \%$ of the total teacher's verbal intervention time. In the CTE students, the total instructional time for both technical and tactical tasks was composed of the percentage of the total practice time (83\%) and the total teacher's verbal intervention time (17\%). These results showed a similar relative proportion of the practice time and the teacher's verbal intervention time during both instruction sessions.

\section{Testing procedures}

With each group, technical skills, decision making and skill execution during a match were assessed in three sessions during the week before and after the training intervention.

\section{Soccer Skill Tests}

The standardized Soccer Skill Test Battery (Mor \& Christian, 1979) was used to assess the execution of the major soccer skills - dribbling, passing and shooting. The total time from two trials of dribling and a number of precise passes and shots were used as the test scores. The validity of the dribbling, passing and shooting tests in adolecent students was found to be $r=0.73,0.78$ and 0.91 , respectively, the test-retest reliability was found to be $r=0.80,0.96$ and 0.98 , respectively (Mor \& Christian, 1979).

A pair of the trained examinors were responsible for the administration of each skill test. Before each test, 
the standardized instructions were provided for each student. In a given test, each student performed a practice trial in dribbling through half of the track, half of the number of passes and shots, respectively, followed immediately by a formal trial in the dribbling, passing and shooting tests, respectively.

\section{Assessment of decison making skill and skill execution}

To assess decision making skill and skill execution during a student game while being in possession of the ball during a soccer match, the Soccer Performance Observation System (SPOS), based on the observation and coding of a player's behaviour from videotape, was developed. The SPOS was constructed based on the methodological principles of the Game Performance Assessment Instrument GPAI (Mitchell, Oslin, \& Griffin, 2006; Griffin, Mitchell, \& Oslin, 1997) (TABLE 2).
Previous instruments for basketball (French \& Thomas, 1987) and field hockey (Turner \& Martinek, 1995) served as guides, too.

The decision making skill related to the selection of a student's movement responses in possession involves three coded variables - dribbling, passing and shooting decision. Skill execution involves four variables - ball control (i.e. receiving a ball under control), dribbling, pass and shot execution. Decision making and skill execution performance were coded as 1 for an appropriate decision and successful execution, respectively, and 0 for an inappropriate decision and unsuccessful execution, respectively. Coding procedures for decision making and skill execution are showed in TABLE 2 . The total variables of decision-making and skill execution performance were counted in accordance with the GPAI (Mitchell et al., 2006) and the Decision Making Index (DMI) as the

TABLE 2

Coding procedures for decision making and skill execution in a match

\begin{tabular}{|c|c|}
\hline Decision making & Skill execution \\
\hline $\begin{array}{l}\text { Dribbling } \\
\text { coded as } 1 \\
\text { 1. Advancing the ball up field in direction to a goal, the player } \\
\text { is not guarded by an opposite player(s). } \\
\text { 2. An appropriate change of direction away from a opposite } \\
\text { player(s) to an open space. } \\
\text { coded as } 0 \\
\text { 1. Obstruction. } \\
\text { 2. Dribbling into an opposite player. } \\
\text { 3. Dribbling out of bounds. } \\
\text { 4. Dribbling away from a goal, without advancing the ball or } \\
\text { attacking the defense. } \\
\text { Passing } \\
\text { coded as } 1 \\
\text { 1. A pass to a teammate who is open. } \\
\text { coded as } 0 \\
\text { 1. A pass made to a teammate who is closely guarded, an oppo- } \\
\text { site player is positioned. } \\
\text { 2. A pass made to a teammate who is closely guarded, an oppo- } \\
\text { site player is positioned. } \\
\text { 3. A pass made to the space where no teammate is positioned. } \\
\text { Shooting } \\
\text { coded as } 1 \\
\text { 1. Any shot taken in the offensive third of the field when the } \\
\text { player was open. } \\
\text { coded as } 0 \\
\text { 1. A shot taken outside the offensive third of the field. } \\
\text { 2. A blocked shot. } \\
\text { 3. Not attempting a shot when open inside the offensive third } \\
\text { of the field. }\end{array}$ & $\begin{array}{l}\text { Control } \\
\text { coded as } 1 \\
\text { 1. The ball is kept close to the player. } \\
\text { coded as } 0 \\
\text { 2. Unsuccessful control, the ball is lost. } \\
\text { Dribbling } \\
\text { coded as } 1 \\
\text { 1. Successfully advancing the ball. } \\
\text { coded as } 0 \\
\text { 1. Loss of control. } \\
\text { 2. Loss of the ball due to legal tackle. } \\
\\
\text { Passing } \\
\text { coded as } 1 \\
\text { 1. Successful pass to a teammate. } \\
\text { coded as } 0 \\
\text { 1. Pass too hard. } \\
\text { 2. Out of bounds. } \\
\text { 3. Too far behind or in front of a teammate. } \\
\text { 4. Interception. } \\
\text { Shooting } \\
\text { coded as } 1 \\
\text { 1. Shot on goal. } \\
\text { coded as } 0 \\
\text { 1. Shot off goal. } \\
\end{array}$ \\
\hline
\end{tabular}


ratio of the number of all appropriate decisions made to all decisions made, and the Skill Execution Index (SEI) as the ratio of the number of all successful skill executions to all skill executions.

In the pilot study, inter-subject reliability (agreement) of the coding of decision making and skill execution variables with the SPOS between two trained independent coders was $81 \%$ and $92 \%$, respectively. The intra subject reliability (agreement) of the coding of decision making and skill execution variables with the SPOS was conducted three times with 30 day brakes in two coders and was higher than $82 \%$ and $94 \%$, respectively.

The content validity of the SPOS is based on the conception of soccer game performance and the curriculum of the soccer course for preservice physical education (PE) students (Author, 1999). The construct validity of the SPOS is determined by the criteria set for the coding of appropriate and inappropriate decisionmaking and successful and unsuccessful skill execution. These criteria were selected according to the principles for the correct execution of skills and tactical principles for the solving of game situations for players in possession of the ball taught in a basic course for PE students.

To assess the students' decision making skill and skill execution, a 5 vs. 5 match (plus one goalkeeper in each team) on a grass field $45 \times 30 \mathrm{~m}$ consisting of two $18 \mathrm{~min}$. halves was organised for each treatment group. During a match, students rotated from the position of the goalkeeper to particular positions on a field after each 3 minutes. So, each subject participated in a match in a total time of $30 \mathrm{~min}$. as a fielder.

Before the pre-treatment match, the $18 \mathrm{~min}$. pilot match was conducted with the same format as the pre-treatment match to form two opposite teams with balanced performance. The rotation of the players' positions was changed every two minutes. During the pilot match, six observers/assessors - students in the last year of their PE master degree program with a specialisation in soccer coaching observed game performance and made written notation related to the assessment of their game performance according to the components of the actions of each student in a match as determined before. On the basis of their observation, each assessor assessed each student using the five rate scale. According to the sum of scale rates assigned by six assessors, the total rank of students was made up. Students placed on the odd and even places of the rank structure built up one and a second opposite team, respectively. The same procedure of game performance assessment using a pilot match was used to build up opposite teams for the posttreatment game performance assessment using the SPOS.

Each pre and post-treatment match was recorded by four video-camcorders S-VHS Panasonic NV-MS2B (Japan), one on each side. Each video-camcorder was operated by one trained technician positioned at a perch. The focal distance of an object glass of moving videocamcorders was selected so that a sufficient width of the space of a field could be recorded with a player in possession in the centre of the picture.

Each game performance recorded was coded by two independent coders blind to group membership. Both coders with soccer player's and coach's experience were trained for using the SPOS.

\section{Statistical methods}

Besides the mean and standard deviation, the Wilcoxon matched pairs signed ranks test (one tailed) and the Mann-Whitney U test (two tailed) were used to test the significance of intra-group and inter group differences of dependent variables, respectively. For the statistical inference, a level of 0.05 significance was selected.

\section{RESULTS}

\section{Results of soccer skill tests}

A significant increase in performance level in the passing test in both treatment groups, but the significant shortening of time in the dribbling test only in the CTA students were found after the training intervention. No significant change to the results in the shooting test in both groups occurred (TABLE 3 ).

\section{TABLE 3}

Results of the soccer skill tests before and after the training intervention in the CTA and CTE students; the significance of changes of the variables (Wilcoxon test: ${ }^{*} \mathrm{p} \leq 0.05,{ }^{*} \mathrm{p} \leq 0.01$ )

\begin{tabular}{|ll|cc|cc|cc|}
\hline \multirow{2}{*}{} & & \multicolumn{2}{|c|}{ Dribbling test } & \multicolumn{2}{c|}{ Passing test } & \multicolumn{2}{c|}{ Shooting test } \\
& & PRE & POST & PRE & POST & PRE & POST \\
time (s) & time (s) & number of correct passes & number of correct shots \\
\hline CTA Group & M & 57.1 & $\mathbf{5 1 . 0}^{* *}$ & 3.7 & $\mathbf{5 . 3}^{*}$ & 3.2 & 4.5 \\
& SD & 5.7 & 5.6 & 0.9 & 1.7 & 1.5 & 2.3 \\
& M & 54.1 & 49.9 & 4.1 & $\mathbf{6 . 0 ^ { * }}$ & 4.4 & 4.4 \\
& SD & 9.6 & 7.4 & 1.7 & 2.4 & 2.0 & 1.6 \\
\hline
\end{tabular}

Legend: PRE and POST- values of the variables measured before and after the training intervention, SD - standard deviation 


\section{TABLE 4}

Selected variables of decision making skill and skill execution in a match before and after the training intervention in the CTA and CTE students; the significance of changes of the variables (Wilcoxon test: ${ }^{*} \mathrm{p} \leq 0.05,{ }^{*} \mathrm{p} \leq 0.01$ )

\begin{tabular}{|l|cccc|cccc|}
\hline & \multicolumn{3}{|c}{ CTA Group } & \multicolumn{3}{c|}{ CTE Group } \\
& \multicolumn{2}{|c}{ PRE } & \multicolumn{2}{c}{ POST } & \multicolumn{3}{c|}{ PRE } & \multicolumn{3}{c|}{ POST } \\
& M & SD & M & SD & M & SD & M & SD \\
& $(\%)$ & $(\%)$ & $(\%)$ & $(\%)$ & $(\%)$ & $(\%)$ & $(\%)$ & $(\%)$ \\
\hline Dribbling Decision & 72.3 & 16.4 & 78.4 & 20.7 & 69.8 & 18.5 & $\mathbf{8 4 . 1}^{*}$ & 12.1 \\
Passing Decisions & 67.8 & 14.1 & $\mathbf{8 2 . 8}^{*}$ & 17.2 & 69.5 & 16.3 & 75.2 & 13.1 \\
Dribbling Execution & 50.9 & 19.7 & 58.4 & 26.4 & 54.3 & 15.2 & $\mathbf{6 7 . 8}^{* *}$ & 10.2 \\
Pass Execution & 44.7 & 13.7 & $\mathbf{5 6 . 6}^{*}$ & 19.6 & 42.5 & 14.9 & $\mathbf{5 6 . 9}^{*}$ & 13.3 \\
Control Execution & 59.6 & 15.3 & $\mathbf{7 3 . 5}^{*}$ & 20.9 & 64.1 & 15.6 & $\mathbf{7 8 . 8}^{*}$ & 20.0 \\
\hline
\end{tabular}

Legend: PRE and POST- values of the variables measured before and after the training intervention, M - mean, SD - standard deviation

The CTA students showed a significant increase in the percentage of appropriate passing decisions but no significant change to dribbling decisions after the intervention (TABLE 4). In the CTE students the opposite effect of the training intervention was found. However, the Decision Making Index (DMI) was significantly enhanced after intervention in both groups of students (Fig. 1).

The percentage of successful execution of all ball actions increased significantly in both groups of students after the intervention, with the exception of no significant change in dribbling execution in CTA students (TABLE 4). The skill execution index (SEI) of both groups of students found from observation analysis of the game's performance were significantly higher in the post-matches in comparison to SEI in the pre-matches (Fig. 2). The percentage of appropriate shot decision and execution were not assessed due to a very low number of shot trials found during matches in most students.

\section{Fig. 1}

Decision-making index (DMI) before and after the training intervention in the CTA and CTE students; the significance of change of DMI (Wilcoxon test: * $p \leq 0.05$, $* * \mathrm{p} \leq 0.01)$

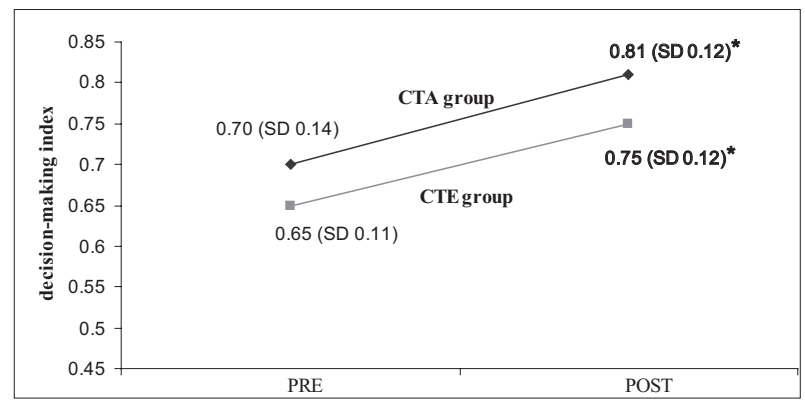

Legend: PRE and POST- the values of DMI measured before and after the training intervention, $\mathrm{M}$ - mean, SD - standard deviation

\section{DISCUSSION}

Using the Mann-Whitney U-test, no differences in the variables of decision making and skill execution between the CTA and CTE students were found neither before or after the intervention $(p>0.05)$. The results suggest that the significant enhancement of decision making skill and skill execution found was not contributed from the potencial effect of an initial lower level of one of both students' groups in a given variable.

The CTE students achieved similar improvement of their decision making skills during a match as the CTA students, although the total time spent teaching tactical skills to CTA students represented $264 \%$ of that provided to CTE students. In addition, the CTE students were taught tactical skills in one block of instruction per week only, in contrast to two blocks provided to CTA students.

Fig. 2

Skill execution index (SEI) before and after the training intervention in the CTA and CTE students; the significance of change of SEI (Wilcoxon test: ${ }^{*} p \leq 0.05$, $* * \mathrm{p} \leq 0.01)$

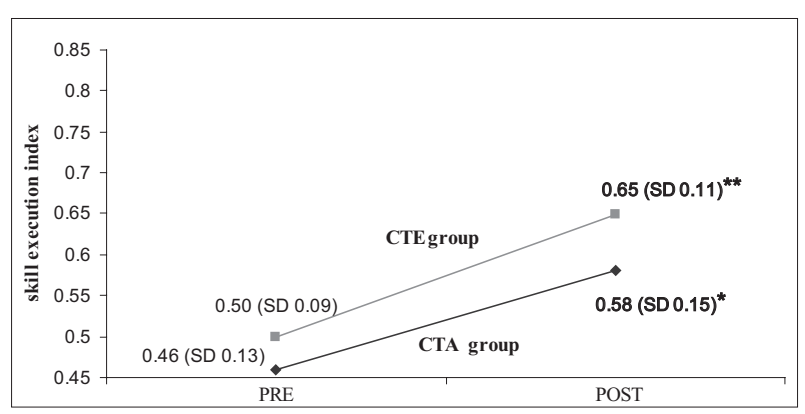

Legend: PRE and POST- the values of SEI measured before and after the training intervention, respectively, M - mean, SD standard deviation 
A similar increase in decision-making skill in both students' groups could have more possible explanations. Firstly, five training blocks focused on tactics with the mean time duration of $25 \mathrm{~min}$. for each block provided to the CTE students this could be of sufficient length to effect a positive change in decision making in any match in physically active young adult women. The intervention studies involving basketball and field hockey instruction in children of an elementary school (Nevett, Rovegno, Babiarz, \& McCaughtry, 2001; Turner \& Martinek 1992, 1995) and with volleyball and tennis instruction in college students (Harrison, Blakemore, Richards, Oliver, Wilkinson, \& Fellingham, 2004; McPherson \& French, 1991) suggested that a significant increase in decision making performance could be already achieved with a minimum amount of seven 35-45 min. lessons of instruction involving a major focus on tactics supplemented with minor teaching techniques.

Secondly, significant increase in the decision-making performance of the CTE students could be contributed to by implicit learning. Matches without the teacher's verbal intervention as a potencial source of implicit learning were provided to both students' groups at the same frequency and with almost the same mean time per each match, $34 \mathrm{~min}$. and $35 \mathrm{~min}$. Then, other stimuli for implicit learning tactics in the CTE students could be provided by their practicing $15 \mathrm{~min}$. per week in instructional forms with an open unpredictable environment - type II game exercises and modified games, although focused on technical skills. Improved decision making was found in students who obtained the volleyball and field hockey instructional units aimed at motor skill development without teaching tactics or with a very small portion of teaching tactics (Harrison, Blakemore, Richards, Oliver, Wilkinson, \& Fellingham, 2004; Turner \& Martinek, 1995).

Thirdly, decision making skill before intervention seemed to be of a high level in both students' groups, when the percentage of appropriate decisions on passing and dribbling was $67-71 \%$. Although the female students in the study obtained no systematic soccer program before the intervention, as physical education students they disposed of a significant degree of sport experience. Then a probable cause, why a more significant improvement in decision making skills in the CTA students was not achieved, could be the fact, that the next development in their decision making would require a longer and more frequent systematic training regime.

An improved degree of ball skill execution in any given match was found in both students' groups with the exception of dribbling execution in the CTA students. Improvement in the execution of a pass in a match in both students' groups was accompanied by significantly improved performance in the test of the skill of passing.
On the other hand, the significant and insignificant improvement of dribbling execution in any given match in CTE students and CTA students, respectively, was not accompanied by the same change of performance in the dribbling test assessed after the intervention. One of the possible explanations could be the lower reliability and validity of the dribbling test in comparison to the test of the skill of passing used (see section on Methods).

What is an explanation of the similar improvement of the offensive on a ball skills in the students' groups with the different time and frequency of teaching tactical and technical skill?

A study with hockey field instruction suggested that 6 lesson course of instruction based on the technical model need not be efficient enough for the improvement of skill execution in a match (Turner \& Martinek, 1992). However, the time, volume and duration of instruction which would be sufficient for the improvement of a technical skill, is dependent on its motoric difficulty. Even a concentrated 17 lesson instructional program with a frequency of three lessons a week did not result in the significant improvement of a tennis stroke in varsity students (McPherson \& French, 1991). One of the explanation, why improvement of the ball control and pass execution in the CTA students was similar to the CTE students, although they were provided with the total time for technical tasks of 95 min. only, in comparison to $309 \mathrm{~min}$. for the CTE students, could be the contribution of the implicit learning of techniques. Implicit learning techniques in the CTA students could be stimulated by practising tactical tasks performed under the conditions of an open unpredictable environment and necessarily involving skill execution.

The shooting skill assessed by the shooting test did not significantly change in either of the students' groups. In both the CTA and CTE program, the instruction on shooting was involved into one and two training blocks, respectively. Other implicit leasing of shooting was limited, when some or all of the technical and tactical tasks provided were finished with a shot into a goal. In addition, trials of shooting in modified games and matches are generally of low frequency and random distribution.

\section{CONCLUSIONS}

This study showed that the combined technical-tactical instructional models for soccer with an emphasized orientation to tactical and technical skills, respectively, can result in the significant improvement of both decision making and skill execution performance in young adult subjects. The study also suggested that decision making skills and skill execution as the major components of game performance can be significantly developed using the mechanism of implicit learning. 


\section{ACKNOWLEDGEMENT}

The study has been supported by the research grant from the Ministry of Education, Youth and Sports of the Czech Republic (No. MSM 6198959221) "Physical Activity and Inactivity of the Inhabitants of the Czech Republic in the Context of Behavioral Changes".

\section{REFERENCES}

Bloom, B. S. (1976). Human characteristics and school learning. New York: Graw-Hill.

Butler, J. I., \& McCahan, B. J. (2005). Teaching games for understanding as a curriculum model. In L. L. Griffin \& J. I. Butler (Eds.), Teaching games for understanding: Theory, research and practice (pp. 33-54). Champaign, IL: Human Kinetics.

Dobrý, L. (1988). Didaktika sportovních her. Praha: SPN.

French, K. E., Werner, P. H., Taylor, K., Hussey, K., \& Jones, J. (1996). The effects of a 6 week unit of tactical, skill, or combined tactical and skill instruction on badminton performance of ninth grade students. Journal of Teaching in Physical Education, $15,439-463$.

French, K. E., \& Thomas, J. (1987). The relationship of knowledge development to children's basketball performance. Journal of Sport Psychology, 9, 15-32.

Griffin, L. L., Mitchell, S. A., \& Oslin, J. L. (1997). Teaching sport concepts and skills: A tactical games approach. Auckland: Human Kinetics.

Gréhaigne, J. F, Richard, J. F., \& Griffin, L. L. (2005). Teaching and learning team sports and games. New York, London: RoutledgeFalmer.

Harrison, J. M., Blakemore, C. L., Richards, R. P., Oliver, J., Wilkinson, C., \& Fellingham, G. (2004). The effects of two instructional models - tactical and skill teaching - on skill development and game play, knowledge, self efficacy, and student perceptions in volleyball. Physical Educator, 61(4), 186-199.

Harrison, J. M., Preece, L. A., Blakemore, C. L., Richards, R. P., Wilkinson, C., \& Fellingham, G. W. (1999). Effects of two instructional models - skill teaching and mastery learning - on skill development, knowledge, self efficacy, and game play in volleyball. Journal of Teaching in Physical Education, 19, 34-57.

McPherson, S. L., \& French, K. E. (1991). Changes in cognitive state and motor skill in tennis. Journal of Sport and Exercise Psychology, 1, 26-41.

Mitchell, S. A., Oslin, J. L., \& Griffin, L. L. (2006). Teaching sport concepts and skills. A tactical games approach (2nd ed.). Champaign, IL: Human Kinetics.
Mor, D., \& Christian, V. (1979). The development of a skill test battery to measure general soccer ability. N. C. J. Health Phys. Ed., 15, 30-39.

Nevett, M., Rovegno, I., Babiarz, M., \& McCaughtry, N. (2001). Changes in basic tactics and motor skills in an invasion type game after a 12 lesson unit of instruction. Journal of Teaching in Physical Education, 20, 352-369.

Psotta, R. (1999). Fotbal. Základní program. Praha: NS Svoboda.

Rink, J. E. (1998). Teaching physical education for learning (3rd ed.). Boston: WCB McGraw-Hill.

Rink, J. E., French, K. E., \& Tjeerdsma, B. L. (1996). Foundations for the learning and instruction of sport and games. J. Teaching Phys. Educ., 15, 399-417.

Starkes, J., Ericsson, K., \& Anders, K. (2003). Expert performance in sport: Advances in research on sport expertise. Champaign, IL: Human Kinetics.

Turner, A. P., \& Martinek, J. (1992). A comparative analysis of two models for teaching games (technique approach and game centered tactical focus approach). Int. J. Phys. Educ., 29, 15-31.

Turner, A. P., \& Martinek, T. J. (1995). Teaching for understanding: A model for improving decision making during game play. Quest, 47, 44-63.

Williams, A. M., \& Hodges, N. J. (Eds.). (2004). Skill acquisition in sport: Research, theory and practice. London: Routledge.

\section{ZMĚNY DOVEDNOSTI V ROZHODOVÁNÍ A PROVEDENÍ ČINNOSTI VE FOTBALOVÉM VÝKONU: INTERVENČNÍ STUDIE}

(Souhrn anglického textu)

VÝCHODISKA: Předchozí studie přinesly kontroverzní výsledky o vývoji dovednosti v rozhodování a dovednosti v provedení činností míčem při uplatnění taktického modelu vyučování sportovní hře.

CÍLE: Cílem studie bylo prozkoumat efekty dvou kombinovaných technicko-taktických modelů vyučování na rozvoj dovednosti v rozhodování a provedení činností s míčem v utkání u studentek.

METODIKA: Dvě skupiny studentek (věk 20,9 $\pm 0,7$ roků) se zúčastnily 5týdenního intervenčního fotbalového tréninku, který byl založen na technicko-taktickém modelu vyučování her, s frekvencí dvou 90minutových tréninkových jednotek týdně. U jedné skupiny studentek byl užit trénink s dominantní orientací na učení taktickým dovednostem, u druhé skupiny na technické dovednosti (CTA, resp. CTE skupina). Dovednosti v rozhodování a provedení činností s míčem byly hodnoceny před a po skončení intervence $\mathrm{z}$ videozáznamu 
utkání pomocí kategoriálního systému pozorování fotbalového výkonu (SPOS). Dovednosti s míčem byly navíc hodnoceny mimo utkání testovou baterií fotbalových dovedností (Mor \& Christian, 1979).

VÝSLEDKY: Index provedení činnosti (SEI) $0,58 \pm 0,15$ a $0,65 \pm 0,11$ zjištěný po intervenci u CTA, resp. u CTE metodou SPOS byl významně vyšší než před intervencí $(0,46 \pm 0,13$, resp. $0,50 \pm 0,09 ; \mathrm{p}<0,05$, resp. $\mathrm{p}<0,01)$. Podobně index rozhodování (DMI) se významně zvýšil po intervenci jak u CTA studentek ( z $0,70 \pm 0,14$ na $0,81 \pm 0,12, p<0,05)$, tak u CTE studentek ( $\mathrm{z} 0,65 \pm 0,11$ na $0,75 \pm 0,12, \mathrm{p}<0,05)$.

ZÁVĚRY: Studie ukázala, že vyučovací modely jak s převahou taktických úloh, tak s převahou technických úloh mohou u mladých dospělých jedinců vést $\mathrm{k}$ významným změnám výkonu v rozhodování a provedení činností s míčem v utkání. Studie naznačila, že na vývoji jak dovednosti $\mathrm{v}$ rozhodování $\mathrm{v}$ herních situacích, tak dovednosti v provedení herní činnosti s míčem se může značně podílet mechanismus implicitního učení.

Kličová slova: motorické učení, vyučování her, taktická dovednost, implicitní učení, technická dovednost, fotbal.

\section{Doc. PaedDr. Rudolf Psotta, Ph.D.}

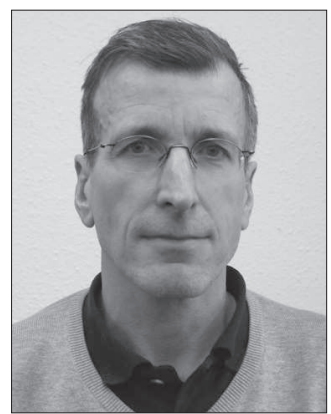

Palacký University

Faculty of Physical Culture

tř. Míru 115

77111 Olomouc

Czech Republic

\section{Education and previous work experience}

He has been affiliated with the Department of Natural Sciences in Kinanthropology at the Palacký University, Faculty of Physical Culture (Czech Republic) as an associate professor. He received his Ph.D. in the kinanthropology from the Charles University in Prague. His scientific interest is focused on the development and diagnostics of physical a motor performance in sports and other areas of human movement behavior. He is an author and coauthor of more than 140 publications, including several books.

\section{First-line publications}

Psotta, R., Bunc, V., Hendl, J., Tenney, D., \& Heller, J. (2011). Is repeated sprint ability of soccer players predictable from field based or laboratory physiological tests? Journal of Sports Medicine and Physical Fitness, 51, 18-25.

Psotta, R., Svěráková, D., Bunc, V., Šeflová, I., \& Hráský, P. (2009). Aerobic fitness, running performance and body composition of Czech elite male summer biathletes. International Journal of Fitness, 5, 41-49.

Psotta, R., Blahuš, P., Cochrane, D., \& Martin, A. J. (2005). The assessment of an intermittent high intensity running test. Journal of Sports Medicine and Physical Fitness, 45, 248-256.

Psotta, R., \& Bunc, V. (2004). An intermittent anaerobic running test: Reliability and factor validity in soccer players. Journal of Sport Sciences, 22, 557-558.

Psotta, R., Bunc, V., Tenney, D., Svěráková, D., Hráský, P., \& Šeflová, I. (2007). Physiological profile of Czech elite summer biathletes of both sexes. Gazetta Medica Italiana Archivio per le Science Mediche, 166, 169-180. 